\title{
Prospek Peningkatan Kualitas Ruang Perumahan dan Pemukiman yang Berbasis pada Komunitas Studi Kasus: Lingkungan Permukiman Jalan Gagak - Bandung
}

\author{
Suparti Amir Salim, Syahyudesrina*, Samsirina \& Fenita Indrasari* \\ *KK Perumahan dan Permukiman, SAPPK, Bandung Institute of Technology
}

\begin{abstract}
This study looks to understand more on the possibility of improving the quality of housing environment based on community initiative that sustain residents' effort to accommodate changes of their surroundings, by observing housing-environment at jalan Gagak - Bandung as an area for case study. The analysis focuses on: (1) the socio-capital of community involvement, stating condition of internal organized efforts in addressing needs of the community, and (2) the roles of external parties, stating the involvement of external actors both of government and privates. For the study, the authors conducted focusgroup discussions on group of residents at RW 18 and RW 19 Kelurahan Sadang Serang, Kecamatan Coblong - Bandung, as well as interviewing local leaders. Results of observation indicate that residents possess interests and self-trust to develop their environment and willing to provide supplies for it. They have tendency to set preferences on what orderly environment should look like including rejecting ideas of apartment-like housing as it is feared to create "slum"-ness and "inappropriateness" fire-emergency access.

As residents put concern on the facts that there are no shared-values among them in addressing problems of space and inactivity of local leaders, resulting in the market-driven changes of spatial development that intervening the needs of public. Thus, it is necessary to decentralize the process of organizing public space, starts from government's unit to community's initiative. This requires strict guidelines that are fair to follow by allowing neutral parties to involve. In addition, there should be internal mechanism to build community's initiative through "musrenbang" as a way to initiate community based development. Having the results, the authors urge future studies on different cases of community and places, to understand the dynamics of development negotiation between interested stakeholders, whether they are formal and/or informal parties.
\end{abstract}

Keywords: community based development; housing environment; socio-capital; urban space.

\section{Pendahuluan}

Peningkatan kualitas hunian perumahan dan permukiman sudah banyak diupayakan, termasuk di kawasan kampung kota dengan pendekatan partisipatif. Namun belum banyak yang sepenuhnya tumbuh berkembang dari komunitas sendiri dan dengan pendekatan yang komprehensif. Pendekatan berbasis 
komunitas umumnya diterapkan pada komunitas yang relatif homogen, dan cenderung berhenti dalam skala 'proyek'.

Dari riset terdahulu yang diadakan oleh KK Perumahan dan PermukimanSAPPK di area studi kasus, terungkap bahwa kampung ini bersifat heterogen, namun tingkat kebetahan tinggal warga relatif tinggi, karena baiknya hubungan sosial dan kemudahan akses ke berbagai kebutuhan sehari-hari. Sedangkan melalui diskusi kelompok terfokus yang diselenggara-kan dalam riset tersebut, juga teridentifikasikan keinginan warga untuk mengajukan isu lingkungan yang mereka hadapi ke tingkat institusi yang lebih tinggi. Di lain pihak, pengembangan ruang perkotaan memerlukan sumberdaya yang dipunyai pihak lain, khususnya pemerintah setempat, dan sumber daya lain yang dapat diakses oleh masyarakat. Berdasarkan informasi tersebut, maka dipandang perlu untuk melakukan riset guna beroleh pemahaman yang lebih mendalam tentang peluang peningkatan kualitas lingkungan perumahan yang berbasis pada inisiatif komunitas setempat.

Pertanyaan penelitian adaa tiga yaitu:

- Sejauh mana penerimaan warga Jalan Gagak terhadap gagasan pembangunan kembali tempat untuk meningkatkan aset dan kualitas tempat

- Sejauh mana aktor pembangun lain (developer, investor/perbankan, dan pemerintah kota) bersedia terlibat dalam pembangunan yang inisiatifnya diambil oleh komunitas

- Informasi apakah yang diperlukan oleh warga/ komunitas untuk menjadi pengambil inisiatif membangun, dan dengan cara bagaimana informasi dapat diperoleh

Dari riset ini diharapkan dapat diungkapkan:

- Proses, potensi dan kendala pembentukan organisasi komunitas setempat untuk peningkatan ruang perumahan dan permukiman, dalam kaitan dengan struktur sosio ekonomi dan politik setempat

- Kendala institusi dan regulasi di tingkat kota dan komunitas terhadap kemung-kinan "desentralisasi" perubahan ruang di tingkat hamparan (kelurahan dan komunitas setempat)

- Akseptabilitas terhadap jenis-jenis perumahan dan perubahan fisik lingkungan

Wilayah studi kasus terletak di Kelurahan Sadang Serang Kecamatan Coblong Kota Bandung. Kelurahan ini terdiri dari $21 \mathrm{RW}$, dan yang menjadi fokus penelitian adalah RW 18 dan RW 19. Wilayah penelitian merupakan area kampung kota yang secara sosio-ekonomi bersifat sangat heterogen. Selain 
berbeda latar belakang etnis dan pendidikan, juga berbeda secara sosioekonomi. Ini tampak jelas dari kondisi bangunan rumah warga yang sangat berbeda: dari yang sangat sederhana, luas tertbatas dan bersempad-an nol serta dapat dikategorikan kumuh sampai dengan bangunan bertingkat dan berhalaman luas.

\section{$2 \quad$ Kerangka Konseptual}

Panduan maupun praktik praktik pembangunan yang bertumpu pada komunitas mensyaratkan adanya pengorganisasian atau organisasi komunitas lokal. Poerbo (1999:44-51) menyebutkan bahwa proses perwujudan (bagian bagian) kota menyangkut kepentingan berbagai pelaku dalam memanfaatkan sumberdaya yang dikuasainya secara langsung maupun tidak langsung, maka para pelaku tersebut haruslah dilibatkan dalam proses perancangan kota sedini mungkin. Pelaku pembangunan tersebut oleh Poerbo dibagi atas 4 kelompok, yaitu (1) Kelompok Pemerintah atau sektor Publik, yang diharapkan dapat berperan sebagai wasit, pengarah, pengatur, pengendali, pengayom dan peran lain yang serupa; (1) Komunitas Usaha dan Swasta Perorangan, atau sektor swasta yang berorientasi pada pencaharian laba serta pengembangan kekayaan (assets); (3) Komunitas atau Kelompok atas Dasar Kebersamaan, yaitu kelompok masyarakat yang mengutamakan kepentingan bersama; dan (4) Perorangan. Kelompok terakhir ini, terutama bila dari kalangan masyarakat miskin, tidak akan mampu menghadapi kelompok aktor lain yang sumberdayanya jauh lebih kuat. Oleh karena itu, Poerbo (1999: 234) berpendapat bahwa perlu diadakan upaya agar kelompok perorangan ini dapat dibentuk sebagai suatu organized client system atau kelompok kepentingan bersama, agar mampu melakukan negosiasi dan tawar menawar yang lebih setara dengan aktor terorganisasi lain yang umumnya lebih mapan dan kuat yaitu sektor publik dan swasta. Pandangan Poerbo ini menyerupai teori proses pembangunan institusi Healey yang melihat proses pembangunannya sebagai proses negosiasi dari para aktor yang terlibat pada setiap event proses pembangunan yang terjadi, dan masing masing aktor tersebut mempunyai sumberdaya serta kepentingannya sendiri (1992:35-37).

Pandangan Poerbo juga mempunyai kesamaan dengan Turner yang menyebutkan bahwa masyarakat miskin memerlukan peran dan keterlibatan sektor publik dalam memenuhi kebutuhan akan infrastruktur fisik maupun ekonominya, namun di lain pihak komunitas perlu mempunyai otonomi dalam memenuhi kebutuhan akan perumahannya. Pandangan kedua pakar perumahan tersebut menyiratkan pentingnya komunitas mempunyai kemampuan untuk memenuhi kebutuhan akan tempatnya, dalam arti bahwa sekttor publik perlu memfasilitasi masyarakat dengan hal-hal yang komunitas tidak mampu 
mengadakannya atau mengaksesnya. Sektor Publik perlu membantu agar masyarakat miskin mampu menolong dirinya sendiri.

Pendekatan pembangunan melalui kelompok masyarakat, dapat dikatakan sudah dijalankan dalam semua proyek pembangunan yang berlandaskan pemberdayaan, antara lain dalam Proyek Penanggulangan Kemiskinan di Perkotaan (P2KP). P2KP menyadari bahwa kemiskinan adalah persoalan struktural dan multi dimensional, sehingga secara umum 'Masyarakat Miskin' sebagai suatu kondisi masyarakat yang berada dalam situasi kerentanan, ketidak-berdayaan, keterisolasian, dan ketidak mampuan untuk menyampaikan aspirasinya. P2KP dijalankan melalui pembentukan dan pengokohan kelembagaan masyarakat, yaitu Badan Keswadayaan Masyarakat (BKM) yang menaungi kegiatan Kelompok Swadaya Masyarakat atau KSM (Kusuma, 2006:3-5)

Tapi dalam praktiknya, keberadaan organisasi masyarakat lebih merupakan persyaratan yang harus dipenuhi untuk menurunkan dana, kurang dalam konteks memberdayakan komunitas yang bersangkutan. Organisasi umumnya dibentuk secara "instan" dan tidak mengakar, karena itu tidak berkelanjutan. Haryani dan Subkhan dalam laporan penelitiannya menyebutkan bahwa relasi yang terjadi antara KSMP dengan BKM menunjukan sebagian besar BKM terlalu dominan sehingga upaya memandirikan dan memberdayakan KSMP menjadi terhambat. Rendahnya kapasitas KSMP dijadikan alasan lebih kuatnya peran BKM, bukan sebaliknya menjadi tantangan tersendiri bagi BKM untuk meningkatkan kapasitas KSM tersebut sebagai proses pembelajaran. Terdapat kecenderungan BKM berfikir instan, "semuanya biar mudah dan cepat selesai".

Pada dekade terakhir ini berkembang pandangan tentang hubungan kapital sosial dan keberhasilan pembangunan, khususnya yang dilakukan oleh komunitas. Kapital sosial suatu masyarakat mencakup kelembagaan, hubungan (relationships), sikap dan nilai nilai yang mendasari interaksi antar manusia dan memberi sumbangan pada perkembangan social dan ekonomi. Kapital sosial merupakan suatu perekat yang menjaga kebersamaan komunitas, mencakup nilai berbagi (shared values), kepercayaan (trust), dan suatu common sense tentang tanggung-jawab terhadap kepentingan masyarakat ('civic" responsibility), yang menjadikan masyarakat tidak hanya sekedar sebagai kumpulan individu (World Bank 1998, dalam socialcapital.pdf:9). Pengertian tentang kapital sosial tersebut menyiratkan bahwa komunitas dengan kapital sosial yang tinggi berpotensi mampu membangun dan meningkatkan kualitas lingkungannya untuk kemanfaatan bersama.

Dari uraian tersebut diatas maka dapat disimpulkan bahwa untuk menilai prospek terhadap pembangunan berbasis komunitas, diperlukan telaah terhadap 
kekuatan internal dan eksternal yang dapat memfasilitasi iklim pembangunan dan mendorong terjadinya pertumbuh-kembangan tempat. Kekuatan dan kelemahan internal yang ditelaah terfokus pada hal hal yang berkaitan dengan keberadaan organisasi lokal yang ada dan yang dipercayai oleh warga, kesediaan warga berbagi sumberdaya yang dipunyai (dana, tenaga dan tanah) atau berpartisipasi dalam pembangunan, dan kepentingan serta kesamaan pandangan terhadap unsur yang perlu dibangun. Sedangkan telaah terhadap kekuatan eksternal dapat mencakup telaah yang relatif luas, yaitu dapat mencakup kebijakan dan peraturan pembangunan permukiman di tingkat yang lebih makro. Oleh karena itu dalam penelitian ini telaah terhadap kekuatan eksternal dilakukan terbatas terhadap praktek pendekatan dan keterlibatan sektor publik dan swasta dalam pembangunan lingkungan perumahan dan permukiman yang selama ini dilakukan dan keterbatasannya dalam mendorong pembangunan berbasis komunitas.

\section{$3 \quad$ Metoda}

Data menyangkut kekuatan internal komunitas merupakan data primer yang diperoleh melalui Diskusi Kelompok Terfokus atau Focus Group Discussion (FGD), yang diadakan sebayak 3 (tiga) kali. FGD pertama dengan tokoh pimpinan setempat, dihadiri oleh 30 orang peserta dan arah diskusi tentang permasalahan yang dihadapi oleh komunitas lokal. FGD kedua diselenggarakan dengan kelompok pengajian ibu-ibu, dengan peserta 30 orang. Dan FGD ketiga melibatkan ibu-ibu yang tergabung dalam Forum Posyandu RW 19 dengan peserta 25 orang. FGD kedua dan FGD ketiga lebih bersifat verifikasi jawaban anggota kelompok ini atas sejumlah pertanyaan dalam kuesioner yang sudah diedarkan dan dikumpulkan sebelumnya, tentang pendapat responden terhadap kondisi sosial dan fisik lingkungan permukiman dan kemungkinan peningkatan kualitasnya. Selain FGD, data primer juga diperoleh dengan wawancara mendalam dengan tokoh setempat dan beberapa warga yang dapat ditemui.

Data primer yang diperoleh melalui pendekatan kualitatif dianalisis dengan melihat kecenderungan pendapat yang ada, yang antara lain juga muncul sebagai hasil FGD. Analisis juga dilakukan untuk melihat adanya kecenderungan konflik, serta diinterpretasi-kan berdasarkan informasikan dari teori yang relevans. Data yang dapat dikuantifikasi dianalisis dengan menggunakan distribusi frekuensi untuk melihat kecenderungan yang ada.

\section{$4 \quad$ Lokasi dan Kondisi Umum Lingkungan Fisik Gagak}

Lokasi studi kasus relatif dekat dengan area pusat pemerintahan Propinsi Jawa Barat, yaitu Gedung Sate, Gasibu dan Monumen Perjuangan Rakyat Jawa Barat. 
Dari gambar 1 tengah tampak hamparan wilayah studi yang bertetanggaan dengan wilayah perumahan terencana. Di wilayah terencana ini harga tanah jauh lebih mahal dibanding dengan daerah kampung tetangganya. Gambar 1 paling kanan menunjukan wilayah RW 18 dan RW 19 yang menjadi area studi

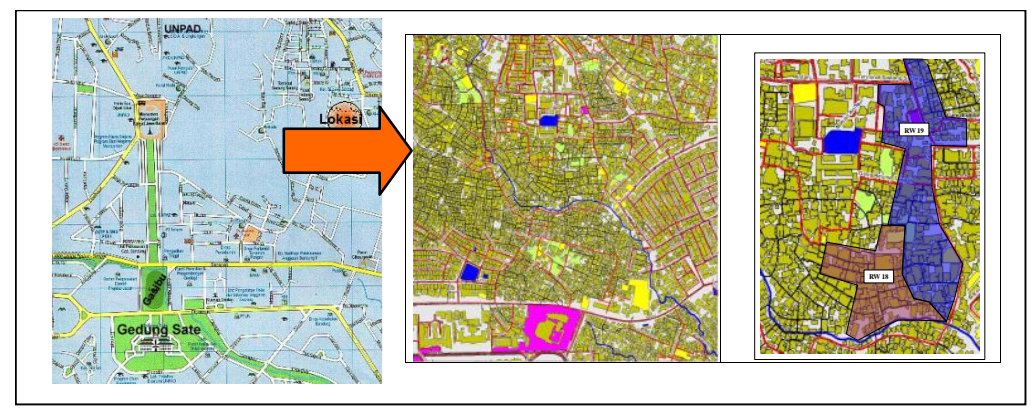

Gambar 1 Lokasi Studi Kasus.

Gambar 2, 3, dan 4 menunjukan kondisi bangunan yang beraneka ragam, baik dalam hal kualitas bangunan, maupun posisinya terhadap batas jalan di depannya. Kondisi bangunan bertingkat pun dapat sangat berbeda kualitas: dari bangunan yang terbuat dari bahan bahan sisa dan tak mempunyai halaman sampai ke bangunan bertingkat yang kualitasnya relatif sama dengan yang terdapat di rumah real estate. Kondisi bangunan rumah ini merefleksikan bahwa komunitas lingkungan Gagak ini bersifat heterogen secara sosio-ekonomi. Sedangkan dari FGD diketahui bahwa latar belakang etnisnya cukup heterogen.

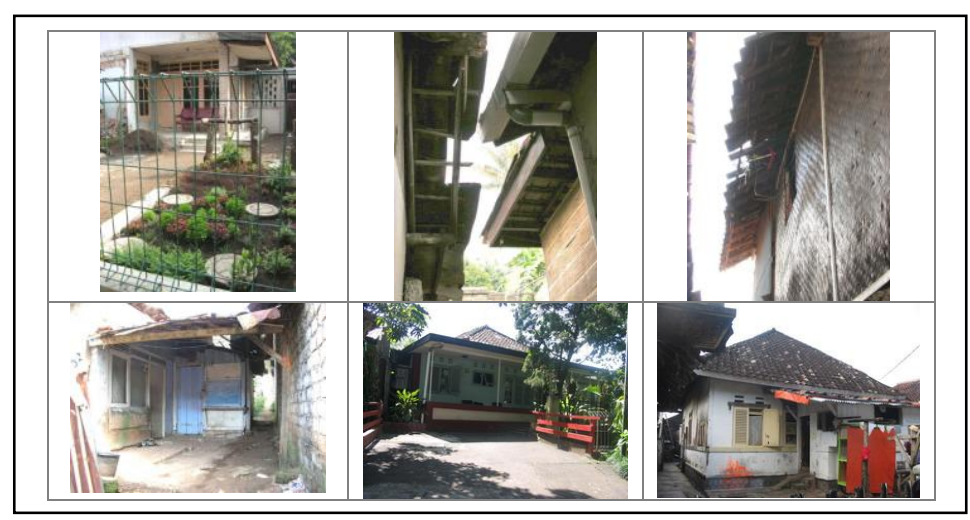

Gambar 2 Aneka Ragam Kondisi Bangunan Rumah.

Sirkulasi terbentuk secara inkremental sesuai dengan kesepakatan tetangga bersebe-rangan yang membangun pertama. Pada umumnya sudah diperkeras. Sebagian melebar dan dapat dimasuki kendaraan mobil serta terdapat tempat parkir mobil. Sebagian dipersempit dengan anak tangga pintu rumah yang 
menjorok ke jalan. Tapi mobilitas orang dipermudah dengan masih mungkinnya jalan pintas menggunakan halaman orang lain. Sementara tanah lapang yang digunakan untuk kegiatan olahraga milik salah seorang warga yang belum dibangun.

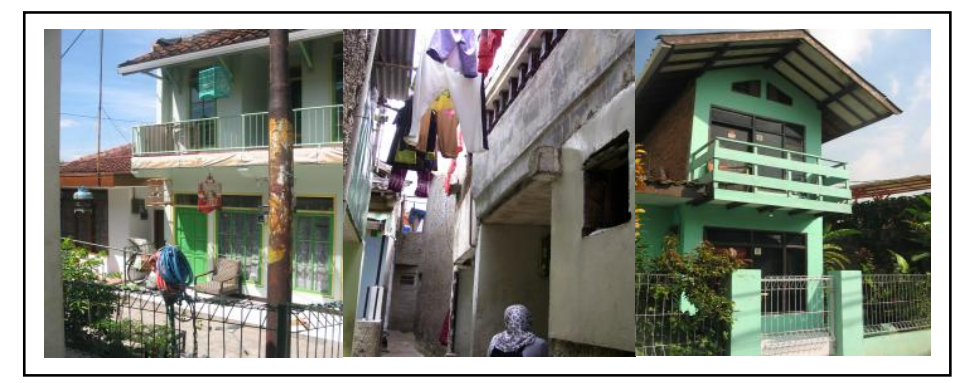

Gambar 3 Aneka Ragam Kondisi Bangunan Rumah Bertingkat.

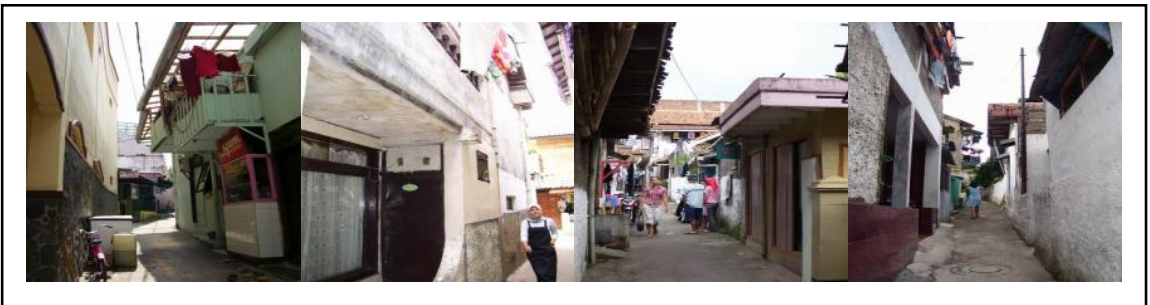

Gambar 4 Bangunan-Bangunan Sempadan Nol.

Status tanahnya sebagian merupakan tanah milik warga setempat, sebagian merupakan tanah sewa dari Pemerintah Kota Bandung. Status pemilik tanah dan bangunan umum-nya jelas, meskipun mungkin tanahnya belum bersertifikat dan tidak mempunyai IMB.

Dilihat dari riwayat perkembangan kampung ini sendiri, tampak bahwa telah terjadi pergeseran dari penduduk setempat lama ke penduduk baru sebagai melalui proses jual beli tanah. Penduduk lama yang menjual tanahnya kemudian pindah, sehingga terjadi komunitas penduduk lama dan baru. Proses ini berlangsung secara inkremental dari waktu ke waktu.

\section{$5 \quad$ Isu Kekuatan Sosial Komunitas dan Permasalahan Fisik Ruang}

Indikasi bahwa warga mempunyai kemampuan mengorganisasikan diri melakukan suatu kegiatan bersama, pelibatan diri dalam kegiatan komunitas serta bekerja bersama secara sukarela tampak dari: 
- Fenomena agustusan, yaitu merayakan hari kemerdekaan dengan berbagai acara kesenian dan olahraga, yang diselenggarakan oleh komunitas studi kasus secara relatif besar.

- Adanya perbaikan fisik secara swadaya, a.l. menggenapi dana bantuan untuk memperbaiki rumah warga miskin, perbaikan lapangan olahraga, mck, tempat pembuangan sampah, pedagang kaki lima, brangkal dan lapangan parkir

Indikasi ini diperkuat oleh hasil FGD dan kuesioner yang disebar terbatas kepada kelompok FGD. Hasil menunjukan bahwa lebih dari $70 \%$ responden menyatakan berminat terlibat, dan bersedia menyumbangkan tenaga serta dana sesuai kemampuan masing-masing. Namun kesediaan ini bersyarat adanya kesepakatan warga tentang apa yang akan dibangun, sedangkan sumbangan sesuai kemampuan masing-masing bukan sesuai kesepakatan

Tapi teramati bahwa warga pada umumnya tak lazim membicarakan permasalahan terkait ruang yang dihadapi oleh sejumlah warga, dan terutama upaya untuk menyelesaikannya, seperti misalnya adanya banjir yang menimpa sebagian warga, terganggunya satu warga oleh warga lain karena penggunaan ruang yang dinilai mengganggu, dan lain sebagainya.

Konflik ruang memang cenderung muncul karena satu warga merasa terganggu oleh tindakan warga lain di ruang publik dekat rumahnya, sementara warga lain tidak merasakan adanya gangguan tersebut. Di lain pihak, suatu peristiwa yang terjadi di lingkungan perumahan dapat merupakan suatu rangkaian aksi dan reaksi atas suatu kebutuhan ruang yang dihadapi oleh warga. Menjemur pakaian di badan jalan, dapat disebabkan oleh tertutupnya sinar matahari ke halaman rumah karena ada tetangga yang ada bangunan tinggi yang didirikan oleh tetangganya.

Sebagian jalan yang dapat dimasuki mobil juga terjadi karena adanya upaya pelebaran dengan cara membeli tanah yang bersangkutan oleh warga yang berkepentingan, tidak terjadi melalui pengorganisasian di tingkat komunitas, dan berjalan secara inkremental. Kasus lain dialami seorang warga di RW 19 yang mengusulkan pelebaran jalan ling-kungan di depan rumahnya kepada tetangganya, agar dapat dilewati oleh becak. Warga yang bersangkutan bersedia untuk menyumbangkan tanah di depan kapling rumahnya asalkan seluruh warga yang dilewati oleh jalan lingkungan tersebut bersedia menyum-bangkan tanah mereka. Akan tetapi, usulan pelebaran jalan ini kemudian terhambat karena ada satu tetangganya yang tidak bersedia menyumbangkan tanahnya untuk pelebaran jalan. 
Proses pengambilan keputusan menjadi titik penting dan rawan dalam kegiatan pembangunan komunitas, karena umumnya belum ada mekanisme untuk menyelesaikan perbedaan pendapat. Dalam kasus pelebaran jalan di RW 19, tampak bahwa tidak adanya peraturan tentang keputusan, menyebabkan mayoritas suara terbanyak warga kalah oleh minoritas. Jadi perlu ada mekanisme yang memungkinkan terlindunginya kepentingan warga yang lebih banyak. Di lain pihak kepentingan warga yang lebih banyak tidak boleh mempersukar warga lain yang minoritas.

Meskipun mayoritas pendapat cenderung sedia membantu dengan sumberdaya masing-masing sesuai kemampuan, akan tetapi terdapat juga pendapat yang berbeda dan bertentangan dengan pendapat terbanyak. Perbedaan pendapat juga terdapat pada aktor yang dipercayai sebagai penyelenggara pembangunan. Kepercayaan kalangan warga cenderung terbagi kepada ketiga aktor pelaku tersebut, yaitu warga sendiri, RT atau RW. Ini mengisyaratkan bahwa aktor pemerintahan lokal yaitu kelurahan dan RT/RW, belum dipercayai secara luas oleh warga, sebagai pihak yang mampu mengelola pembangunan maupun pembiayaannya. Dalam kasus pembangunan nyata, perbedaan ini dapat menjadi ganjalan terselenggaranya pembangunan, bilamana keputusan harus didukung oleh semua warga bukan sekedar mayoritas.

Fenomena di wilayah penelitian tampaknya menggambarkan kondisi umum kepemimpinan lokal perkotaan, yang tampaknya tidak lagi cukup mengakar dalam komunitasnya. Lurah dengan perangkat kelurahannya di daerah perkotaan, cenderung lebih tidak dikenal oleh warganya. Di pihak lain, lembaga RT dan RW lebih merupakan lembaga volunteer. Sumber kehidupannya ada di tempat lain, sehingga dapat dimengerti bahwa kewajiban atau tugas tugas keRW-an atau ke-RT-annya, hanya akan dilakukan di antara waktu lu-angnya.

Kondisi tersebut tampaknya akan mempersulit perbaikan ruang fisik oleh komunitas. Juga menjadi pertanyaan tentang keputusan pembangunan melalui Musyawarah Rencana Pembangunan (Musrenbang) yang pesertanya adalah dari kalangan pemerintah dan perwakilan lembaga masyarakat seperti LPM, RW, PKK dan Karang Taruna. Yang belum terungkap jelas dari keterlibatan aktor sektor publik tersebut itu adalah proses menjadi terlibatnya, apakah merupakan bagian dari keputusan "top down", yaitu diputuskan oleh proyek sektoral yang bersangkutan, ataukah hasil dari "bottom up", yang mengisyaratkan keberhasilan usulan kecamatan. Selain belum jelas bagaimana sesungguhnya jejaring pengambilan keputusan dengan tingkat yang lebih atas, demikian juga dengan tingkat yang lebih bawah, yaitu antara Musrenbang dengan RT dan dan terutama dengan warga. 
Dari Focus Group Discussion (FGD) dan wawancara yang dilakukan tampak bahwa pengetahuan tentang adanya rencana pembangunan di tingkat kelurahan dan peluang memperoleh bantuan dari lembaga publik sektoral, hanya terbatas pada kalangan tertentu saja. Di tingkat lokal pun dapat dijumpai sejumlah kekuatan politis, termasuk dari Lembaga Swadaya Masyarakat (LSM), yang tampak mempunyai pandangan sendiri dan cenderung memandang kekuatan lain sebagai pesaing bukan mitra. Pembangunan masih tampak dilihat sebagai sebatas Proyek.

Ruang tampak belum ditempatkan sebagai urusan komunitas. Konflik ruang antar individu cenderung lebih dilihat sebagai urusan toleransi antar individu. Latar belakang sosio-budaya tampak mempengaruhi sikap yang cenderung meredam konflik terbuka. Namun demikian, ada kecenderungan agar ada peraturan yang diterapkan untuk mengendalikan pembangunan fisik. Ruang publik harus diatur penggunaannya, agar tidak terjadi konflik. Proses penyusunan pengaturan lingkungan tersebut dikehendaki agar melibatkan warga, isinya diketahui serta disetujui oleh warga. Demikian juga warga cenderung menghendaki mengetahui informasi tentang perubahan lingkungan yang akan terjadi.

Dilihat dari pendapat responden atas jenis perumahan terdapat indikasi kuat bahwa yang diinginkan adalah suatu lingkungan perumahan yang mempunyai keteraturan fisik ruang. Ini dapat diartikan bahwa perbaikan yang dilakukan adalah perbaikan yang sifatnya menuju kepada tingkat keteraturan lingkungan perumahan yang lebih tinggi, baik dalam pola fisik ruangnya maupun dalam penggunaannya. Tapi umumnya menolak rumah susun, yang dinilai warga sebagai bangunan besar yang kumuh, dan kurang akses terhadap penyelamatan diri dalam kebakaran.

Namun karena penelitian ini tidak bersifat untuk ditindak-lanjuti dengan kegiatan fisik, maka tidak dibangun diskusi tentang implikasi perubahan dari tipe kampung menjadi perumahan teratur, yang mungkin akan berarti suatu penataan ulang, yang selanjutnya mungkin berimplikasi kepada kemungkingan adanya relokasi atau kombinasi dengan jenis-jenis perumahan berkepadatan tinggi lainnya, seperti rumah susun. Padahal rumah susun terindikasi bukan merupakan pilihan warga. Sementara tentang keteraturan penggunaan, bukanlah pada pengaturan jenis kegiatannya semata, melainkan bahwa penggunaan ruang tersebut khususnya di ruang publik haruslah didasarkan kepada kesepa-katan bersama.

Dari pengalaman Gerakan Melati yang dialami oleh Kelompok pengajian Ibuibu, tampak bahwa untuk sesuatu yang belum menjadi perhatian komunitas, kegiatan perlu digerakan oleh seorang tokoh. Gerakan Melati digerakan oleh 
tokoh formal tingkat kota dan tidak berkelanjutan. Untuk berhasilnya suatu gerakan, tampaknya diperlukan fasilitasi oleh tokoh dari kalangan pimpinan, sementara pengambil inisiatif sendiri mungkin dari kalangan warga sendiri. Kasus usulan pelebaran jalan di RW-19 yang tak jadi terselenggara, mungkin juga tidak ada fasilitasi dari kalangan tokoh lain seperti warga pengusul pelebaran jalan. Sedangkan kasus Gerakan Melati, tampaknya karena inisiatif tidak tumbuh dan tidak ditumbuhkan dari kalangan warga sendiri, sehingga terjadi ketergantungan yang besar kepada tokoh, dan pada akhirnya tidak berkelanjutan

Dari upaya perbaikan lingkungan yang sudah dilakukan, sudah ada praktekpraktek pembangunan yang bersifat berbagi bersama (sharing) antara pemerintah dan warga masyarakat. Pada umumnya pola pembangunan yang bersifat top down. tidak dihendaki. Pola berbagi bersama dalam pembangunan lingkungan tampak menjadi pilihan warga. Akan tetapi pilihan terhadap pelaksanaan berbagi bersama tersebut tidak sama, dan tidak ada cara yang terpilih secara dominan. Perbedaan pendapat yang tampaknya akan sama besar, mungkin dapat menjadi penghambat kelancaran kegiatan. Dalam lingkungan masyarakat sendiri belum tampak dilakukan praktek pengambilan keputusan dengan pemungutan suara, secara luas.

Warga setempat belum mempunyai pengalaman membangun bersama sektor swasta. Aktor ini lebih dikenal sebagai kontraktor bagi sektor publik atau perorangan yang membangun. Aktor swasta tampaknya lebih memilih mekanisme pasar dalam membangun tempatnya, bukan pola berbagi bersama.

\section{Simpulan}

Gejala adanya prospek baik diisyaratkan oleh adanya indikasi kuat bahwa warga mempunyai kepercayaan terhadap kemampuan sendiri untuk membangun, mempunyai minat relatif besar untuk membangun lingkungannya, dan bersedia memberikan sumberdaya yang dimilikinya sesuai kemampuan. Namun demikian, masih diperlukan waktu yang mungkin tidak sebentar untuk mereduksi berbagai hal yang menghambat terwujudnya kemampuan warga membangun tempatnya. Faktor ini dapat berasal dari lingkungan komunitas sendiri, maupun bersifat eksternal, yaitu faktor-faktor yang menyangkut kondisi dan karakteristik lingkungan pembangunan yang lebih makro sifatnya. Faktor tersebut antara lain adalah:

- Kepranataan lokal: Belum terbiasanya komunitas mengurusi masalah ruang sebagai kepentingan bersama, yang harus dioperasikan, dipelihara, dikendalikan dan mung-kin dibangun kembali sesuai dengan perubahan yang terjadi. Sharing value tentang ruang fisik belum terbentuk, karena itu 
kepatuhan terhadap penataan dan konflik sosial yang terjadi akibat kondisi fisik ruang masih merupakan tantangan yang akan sukar diatasi. Selain itu, komunitas belum mempunyai mekanisme pengambilan keputusan yang memfasilitasi kelompok kepentingan warga yang lebih besar, dan terutama belum terbangun kepercayaan warga terhadap kemampuan lembaga setempat dalam membangun tempat.

- Transparansi informasi: alir informasi dari warga ke pengambilan keputusan membangun dan sebaliknya belum terbuka baik; warga masih belum dapat mengungkapkan semua pendapatnya tentang perilaku yang mengganggu dari sesama warga, dan belum mampu membahasnya untuk mencari solusi

- Pendekatan pemberdayaan yang cenderung dikerdilkan sebatas proyek

Kendala kelembagaan lokal cukup luas. Di atas kertas, lembaga RW (Rukun Warga) tampaknya dapat merupakan lembaga lokal terkecil yang seharusnya menjadi ujung tombak pembangunan lokal. Di wilayah studi kasus sudah terbentuk Forum RW. Forum RW seharusnya mempunyai peran penting, karena pemecahan masalah ruang seringkali tak dapat dibatasi menurut wilayah administrasi, melainkan harus lintas wilayah. Namun keberadaan Forum RW tidak terlalu dikenal warga kampung, bahkan tidak ada yang menyebutkan keberadaanya pada diskusi kelompok di tingkat RW. Di lain pihak, ada kelompok kekuatan yang mempertanyakan kedudukan dan peran dari Forum RW ini dalam upaya peningkatan kualitas lingkungan. Pihak ini tampak kurang mempercayai kemampuan Forum RW.

Terdapat indikasi bahwa warga yang tak setuju terhadap suatu keputusan bersama, tak perlu menghormati atau mentaatinya, bilamana yang bersangkutan tidak setuju. Dalam masyarakat yang heterogen, tampaknya akan sangat sukar beroleh keputusan yang disetujui bulat oleh semua warga. Gejala ini berpotensi menghasilkan kemenangan pada suara minoritas yang dominan. Wilayah penelitian merupakan kampung dengan karakteristik sosio ekonomi yang heterogen. Penataan ruang termasuk penggunaan berdasarkan kesepakatan warga berpotensi "dimenangkan" oleh kekuatan kelompok warga yang mempunyai daya negosiasi tinggi, yang biasanya bukan dari kalangan orang miskin.

Implikasi terhadap kebijakan pembangunan tempat adalah perlu ada "desentraliasi" penataan atau urusan fisik ruang secara lebih eksplisit dan jelas dari Pemerintah Kota ke tingkat komunitas. Karena komunitas dan organisasi lokal perkotaan yang tampak masih mempunyai hubungan ketetanggaan adalah RT/RW, maka "desentralisasi" ini perlu sampai ke tingkat RW. Akan tetapi tidak sepenuhnya pengaturan dapat diserahkan kepada warga. Selain tempat dan komunitas lokal merupakan bagian tak terpisahkan dengan tempat dan 
komunitas yang lebih besar, komunitas lokal dapat bersifat sangat heterogen dengan kepentingan yang tidak sama. Karena itu, masih diperlukan suatu rambu-rambu dan atau mekanisme yang memungkinkan terlibatnya pihak ketiga yang netral. "Pihak yang netral" ini antara lain dapat berfungsi sebagai pemberi informasi yang seimbang kepada semua pihak, sehingga informasi tentang manfaat dan dampak buruk yang mungkin terjadi akibat suatu keputusan terhadap seluruh atau sebagian warga, dapat dimiliki relatif seimbang oleh pihak-pihak yang terlibat dalam pengambilan keputusan tersebut. Pihak yang netral ini mungkin tenaga profesional, perguruan tinggi, atau lembaga swadaya yang mempunyai dedikasi kepada pemberdayaan masyarakat.

Adanya "pihak yang netral" merupakan salah satu pemikiran Hasan Poerbo untuk menjem-batani perbedaan kepentingan di antara para aktor yang terlibat, yang disebutkannya sebagai Konsultan Pembangunan. Pemikirannya sudah dipraktekkan juga, khususnya di bidang peru-mahan dan terutama untuk pembangunan perumahan baru. Di berbagai proyek pembangunan pun yang pelaksanannya melalui kelompok masyarakat atau dengan pendekatan pemberdayaan, umumnya ditunjuk konsultan pendamping sebagai fasilitator. Konsultan pendamping ini mungkin berasal dari organisasi lembaga swadaya masyarakat. Tetapi gagasan Hasan Poerbo tentang peran Konsultan Pembangunan sebagai lembaga mediasi umtuk mempertemukan berbagai kepentingan aktor, tampaknya cenderung hanya berjalan di atas kertas. Dari pengamatan secara umum terhadap praktek praktek yang ada, tampak bahwa sektor publik sendiri mempunyai aturan ketat yang tak dapat dinegosiasi, misalnya yang terkait dengan anggaran pembangunan dan jenis sarana yang dibangun. Kondisi ini menyebabkan tidak selarasnya antara timing kesiapan masyarakat dengan turunnya dana -terlalu cepat atau terlalu lambat-. Menurut pengamatan umum, kondisi itu menyebabkan musyawarah yang diadakan bersifat semu, sebagai syarat untuk turunnya dana; atau sebaliknay semangat masyarakat sudah sangat menurun ketika dana tersedia.

Keberhasilan Grameen Bank dalam memberdayakan kaum miskin -khsusunya perempaun- di Bangladesh, melalui kelompok usaha, tampaknya berkaitan dengan adanya keselarasan waktu kesiapan sosial dengan sistem pendanaan kegiatan. Selain itu juga, ada pengawasan secara berjenjang yang terus menerus yang dilakukan, baik di dalam kelompok maupun di tingkat fasilitator serta lembaga yang lebih tinggi. Dalam Grameen Bank, tampaknya aturan aturan yang mendasar yang berimplikasi langsung kepada pemberdayaan, dapat disesuaikan dengan karakter dan kemampuan sosio-ekonomi kelompok yang diberdayakan. Dengan kata lain, semua aktor yang terlibat mungkin bertindak sesuai dengan karakter dan kemampuan sosio-ekonominya masing-masing, dan juga dengan peran yang dibawakannya. Jadi, jika sektor publik berperan sebagai "enabler", maka haruslah sektor ini mempunyai sumberdaya dan aturan aturan 
yang dapat diakses, terjangkau serta sesuai dengan karakter sosio-ekonomi dari masyarakat yang akan dimampukannya

Uraian tersebut di atas lebih berkaitan dengan pembangunan dalam konteks proyek atau program. Dalam konteks ini aktor mediasi dapat dimunculkan, seperti halnya dengan kehadiran konsultan pendamping atau fasilitator pada banyak proyek pembangunan di Indonesia. Tetapi bagaimana menggerakan suatu komunitas yang berpotensi membangun untuk "bergerak" memperbaiki lingkungannya? Pengamatan umum menunjukan bahwa suatu perubahan mungkin terjadi bila ada seseorang yang mampu berinisiatif, dan kemudian menggerakan serta memelihara kegiatan yang dikembangkannya, seperti misalnya arisan perumahan Ibu Atikah. Tokoh tokoh lingkungan yang diberi penghargaan pada hari Habitat, mengindikasikan besarnya peran pengambil inisiatif serta bersedia melakukan "kegiatan percontohan" untuk lingkungan sekitarnya. Namun kegiatan yang ditumbuhkannya, akan berawal dari sesuatu yang menarik minat pembangkit prakarsa.

Model pembangunan bertumpu pada masyarakat dari Hasan Poerbo menempatkan aktor Pemerintah sebagai pelindung atau pengayom, pendorong dan sekaligus pengendali dari pembangunan. Penafsiran dan penterjemahan yang tepat dari peran ini dalam konteks "help them to help themselves" diperkirakan dapat menumbuhkan-kembangkan inisiatif dan aktivitas dari bawah untuk membangun lingkungannya. Pada kasus Gagak, tampak bahwa gagasan dan inisiatif itu ada, seperti misalnya keinginan untuk melebarkan jalan, tetapi inisiatif tersebut terhambat karena tidak ada payung kelembagaan yang mampu menjadi acuan keputusan membangun secara lokal. Bila ada misalnya aturan yang menyebutkan bahwa keputusan setempat yang didukung oleh lebih dari 50\% penghuni dapat dijalankan, atau lembaga mediasi setempat yang dapat memberikan pencerahan terhadap kepentingan yang berbeda, kemungkinan mengembangkan inisiatif lokal menjadi aktivitas pembangunan tampaknya akan lebih besar. Kegiatan musrenbang atau musyawarah pembangunan yang lazim diadakan di tingkat kelurahan atau desa menjelang penyusunan rencana pembangunan pemerintah, tampaknya dapat menjadi isntrumen mediasi. Tentunya musrenbang ini perlu ditempatkan tidak hanya dalam konteks membuat usulan rencana kepada lembaga pemerintah yang lebih atas, melainkan juga dalam memecahkan persoalan pembangunan setempat yang disulkan atai diprakarsai oleh masyarakat. Kapital sosial sendiri, menurut Fukuyama (1999) dapat ditingkatkan secara tidak langsung oleh sektor publik, bila sektor ini dapat menyediakan secara efisien barang barang publik (public goods), khususnya hak atas properti dan keselamatan publik.

Pendekatan pembangunan dengan pemberdayaan masyarakat telah diterapkan hampir pada semua proyek pemerintah yang berkaitan dengan peningkatan 
kesejahteraan warga. Namun masih belum tampak adanya transformasi dari keberhasilan menjadi suatu kegiatan yang berkesinambungan, seperti yang ditunjukan oleh Grameen Bank. Oleh karena itu, perlu dilakukan penelitian yang serupa dengan penelitian ini, agar dapat dikembangkan informasi bagaimana mengintervensi komunitas secara tepat, agar dapat berkemampuan membangun secara lebih nyata. Kasus-kasus studi diperluas dengan tempat lain, yang sifat fisik maupun kondisi sosio-ekonomi penghuni lingkungan perumahannya berbeda: kampung, perumahan terencana formal yang horisontal maupun vertikal atau rusun.

Perlu dilakukan penelitian kelembagaan pembangunan di tingkat desa atau kelurahan, untuk memahami bagaimana informasi dari warga melalui RT/ RW dan kelompok-kelompok warga setempat pengajian, karang taruna dan lain sebagainya sampai ke Musrenbang, dan dinamika negosiasi pembangunan yang terjadi diantara para petaruh (stakeholder) sehingga menghasilkan keputusan pembangunan yang menjadi aliran balik informasi kepada warga, dan selanjutnya menjadi kegiatan nyata. Demikian juga diperlukan penelitian terhadap kelembagaan pemerintah yang lebih makro untuk dapat mengungkapkan kelenturan kelembagaan ini dalam menjalankan perannya sebagai "enabler". Pendekatan yang dilakukan adalah dengan melihat pembangunan sebagai proses negosiasi dari para aktor yang terlibat, sebagaimana dinyatakan oleh teori Healey.

\section{Daftar Pustaka}

[1] Alesina, A., La Ferrara, E., 1999, Participation in Heterogeneous Communities. NBER Working Paper 7155. National Bureau of Economic Research, Cambridge, Mass.

[2] Beddies, S., 2000, URBAN: A Critical Case Study of the Formulation and Operationalisation of a Community Initiative. Ph.D. diss. Department of Social Policy, London School of Economics and Political Science, U.K..

[3] Cernea, M., Kudat, A., ed., 1997, Social Assessments for Better Development: Case Studies in Russia and Central Asia, dalam Environmentally Sustainable Development Studies and Monographs. Series 16. World Bank, Washington, D.C.

[4] Dayal, R., van Wijk, C., Mukherjee, N., 2000, Methodology for Participatory Assessments with Communities, Institutions and Policy Makers. Water and Sanitation Program. World Bank, Washington, D.C..

[5] Fukuyama, F., Social Capital and Civil Society, download dari http://www.imf.org/external/ pubs/ft/seminar/1999/reforms/fukuyama.htm 
[6] Grootaert, C., Narayan, D., 2000, Local Institutions, Poverty, and Household Welfare in Bolivia, Local Level Institutions Working Paper 9, Social Development Department, World Bank, Washington, D.C.

[7] Grootaert, Christiaan, Gi-Taik Oh, \& Anand Swamy, 1999, Social Capital and Development Outcomes in Burkina Faso, Local Level Institutions Working Paper 7. Social Development Department. World Bank, Washington, D.C.

[8] Grootaert, C., 1999, Does Social Capital Help the Poor? A Synthesis of Findings from the Local Level Institutions Studies in Bolivia, Burkina Faso, and Indonesia, Social Development Department. World Bank, Washington, D.C.

[9] Grootaert, C., 1999, Social Capital, Household Welfare, and Poverty in Indonesia, Local Level Institutions Working Paper 6. Social Development Department, World Bank, Washington, D.C.

[10] Haryani, S., Subkhan, I., Studi Efektifitas Pelaksanaan Proyek Penanggulangan Kemiskinan Perkotaan-Rehabilitasi dan Rekonstruksi Masyarakat dan Permukiman Berbasis Komunitas (P2KP-REKOMPAK) di Kabupaten Bantul, Yogyakarta. Download Losdiy-laporan Penelitian P2KP-Rekompak.pdf.

[11] Healey, P., 1992, An Institutional Model of the Developmen Process, Journal of Property Research 9, 33-44.

[12] Hikmat, R.H., 2001, Strategi Pemberdayaan Masyarakat, Bandung, Humaniora Utama Press.

[13] Ian F.S., 1979, Planning for Community (The Mythology of Community Development and social Planning), New Zealand, The Dunmore Press.

[14] Juliantara, D., 2003, Pembaruan Desa: Bertumpu pada yang Terbawah. Yogyakarta: LAPPERA Pustaka Utama.

[15] Kartasamita, G., 1996, Pembangunan Untuk Rakyat: Memadukan dan Pemerataan, Jakarta: Pustaka CIDESINDO.

[16] Kessides, C., 1997,World Bank Experience with the Provision of Infrastructure Services for the Urban Poor: Preliminary Identification and Review of Best Practices, Urban Development Division, World Bank, Washington D.C.

[17] Korten, D.C., Klauss, R., 1984, People Centered Development: Contributions Toward Theory and Planning Frameworks, USA: Kumarian Press.

[18] Korten, D.C., 1992, People Centered Development: Reflections on Development Theory and Methods. Manila.

[19] Krishna, A., 2000, Organizing in Support of CDD: Information Is the Key Resource, Cornell University, Ithaca, N.Y.

[20] Khudori, D., 2002, Menuju Kampung Kemerdekaan, Yayasan Pondok Rakyat, Yogyakarta. 
[21] Kusuma, S., P2KP-Urban Poverty Project, download dari http://p2kpurbanpoverty.blogspot.com/

[22] Mainsah, E., et al., Grameen Bank: Taking Capitalism to the Poor, 2004, download Grameen_Bank_v04.pdf

[23] Malombe, J., 2000, Community Development Foundations: Emerging Partnerships to Support Sustainable Community Development, Draft in progress. World Bank, Washington, D.C.

[24] Manor, J., 1991, The Political Economy of Democratic Decentralization. Directions in Development Series. World Bank, Washington, D.C., 1999

[25] Max-Neef, M., Human Scale Development: Conception, Application, and Further Reflections, London: Apex Press, 1991.

[26] Narayan, D., (et al), 2000, Voices of the Poor: Can Anyone Hear Us? Washington, D.C.: World Bank and Oxford University Press.

[27] Narayan, D., 1995, Designing Community Based Development, Environment Department Working Paper 7. World Bank, Washington, D.C..

[28] Ostrom, E., Chroeder, L., Wynne,S., 1993, Institutional Incentives and Sustainable Development: Infrastructure Policies in Perspective, Boulder, Colo.: Westview Press.

[29] Panudju, Bambang, Dr.,Ir., M.Phil., 1999, Pengadaan Perumahan Kota Dengan Peran Serta Masyarakat Berpenghasilan Rendah, Alumni, Bandung.

[30] Direktorat Jenderal Perumahan dan Permukiman Departemen Permukiman dan Prasarana Wilayah, 2003, Pedoman Teknis dan Pedoman Umum 'Urban Poverty Project', Bersama Membangun Kemandirian Dalam Pengembangan Masyarakat Menuju Perumahan dan Permukiman yang Berkelanjutan, Proyek Penanggulangan Kemiskinan di Perkotaan P2KP.

[31] Poerbo, Hasan, Prof., 1999, Gelar Nalar Prof. Hasan Poerbo, Yayasan Akatiga.

[32] Productivity Commission 2003, Social Capital: Reviewing the Concept and its Policy Implications, Research Paper, AusInfo, Canberra. 